\title{
DNA Barcoding approach reveals 17 exploited fish species, including an unrecognised species of the yellow-lined snapper complex
}

\author{
ADIBAH ABU BAKAR $\ddagger$, Siti Azizah Mohd Nor§ \\ ‡ Universiti Pendidikan Sultan Idris, 35900 Tg Malim, Perak, Tanjong Malim, Malaysia \\ $\S$ Institute of Marine Biotechnology, Universiti Malaysia Terengganu (UMT), 21030, Kuala Terengganu, Terengganu, Kuala \\ Terengganu, Malaysia
}

Corresponding author: ADIBAH ABU BAKAR (adibah@fsmt.upsi.edu.my)

Received: 04 Mar 2021 | Published: 04 Mar 2021

Citation: ABU BAKAR A, Mohd Nor SA (2021) DNA Barcoding approach reveals 17 exploited fish species, including an unrecognised species of the yellow-lined snapper complex. ARPHA Conference Abstracts 4: e65494. https://doi.org/10.3897/aca.4.e65494

\begin{abstract}
Management of wild fisheries resources requires accurate knowledge on which species are being routinely exploited, but it can be hard to identify fishes to species level, especially in speciose fish groups where colour patterns vary with age. Snappers of the genus Lutjanus represent one such group, where fishes can be hard to identify and as a result fisheries statistics fail to capture species-level taxonomic information. This study employs DNA barcoding approaches to identify adult and juvenile Lutjanus species harvested in Malaysian wild-capture fishery. We uncovered two divergent groups of bigeye snapper (' Lutjanus lutjanus') distributed on either side of the Malay Peninsula, displaying a biogeographical pattern similar to distributions observed for many co-occurring reef distributed fish groups. One of these bigeye snapper groups almost certainly represents an unrecognized species in need of taxonomic description. The study demonstrates the utility of DNA barcoding in identifying overlooked diversity and for assessing species catch composition in a complicated but economically important taxonomic group.
\end{abstract}




\section{Keywords}

DNA barcoding, genetic divergence, marine fisheries, phylogeny, species identification

\section{Presenting author}

Adibah Abu Bakar

\section{Presented at}

1st DNAQUA International Conference (March 9-11, 2021)

\section{Acknowledgements}

We thank En. Abdul Rahman Abdul Majid for assistance during sampling, KW Conway for help with anatomical terms, colleagues from Lab 308, USM and Genomic Lab, UPSI for stimulating discussions and insightful comments.

\section{Funding program}

Delivering Excellence Grant 1002/PBIOLOGI/910317: DNA Barcoding and GenomicsEnsuring Sustainable Fisheries Malaysia and Research University Grant (1001/PBiology/ 815087)

\section{Grant title}

1002/PBIOLOGI/910317: DNA Barcoding and Genomics-Ensuring Sustainable Fisheries Malaysia and Research University Grant (1001/PBiology/815087)

\section{Hosting institution}

Universiti Pendidikan Sultan Idris (UPSI)

Universiti Sains Malaysia (USM) 


\section{Ethics and security}

All fish products examined in this study were commercial products available in markets and retailers. Permission to undertake collection was not required because it did not involve extinct species or wildlife trades.

\section{Author contributions}

Adibah Abu Bakar: Field sampling and data analysis

M. Siti Azizah: Funding acquisition and data analysis.

\section{Conflicts of interest}

The authors declared that no competing interests exist. 